\title{
KARAKTERISTIK FISIK, KIMIA DAN ORGANOLEPTIK MIE KERING PADA BERBAGAI RASIO TEPUNG BONGGOL PISANG KEPOK
}

\author{
Asnani ${ }^{1}$, Abdul Rahim ${ }^{2}$, If all ${ }^{1 *}$ \\ ${ }^{1}$ Program Studi Teknologi Hasil Pertanian, Fakultas Pertanian, Universitas Alkhairaat \\ Palu \\ ${ }^{2}$ Program Studi Agroteknologi, Fakultas Pertanian, Universitas Tadulako Palu \\ Email :ifall@unisapalu.ac.id
}

\begin{abstract}
This work deals with the effect of banana (sweet plaintain or 'kepok' variety) hump flour substituted to wheat flour in the making of noodle, on physical, chemical, and sensory characteristics of noodle. A completely randomized was employed, with three replicates. Sensory analysis was conducted according to randomized group design. Four proportions of banana hump to wheat flour (10:90, 20:80, 30:70, and 40:60, weight basis) was studied. Results showed that the best physical and chemical characteristics was shown by noodle made from 10:90 proportion of banana hump to wheat flour, with $4.59 \%$ water absorption, $0.57 \%$ cooking loss, $10.37 \%$ water content, $34.21 \%$ starch content. However, result of sensory analysis suggested that the most liked noodle was that made from flour proportion of 20:80 with 'like' for colour, 'like very much' for aroma, 'like' for texture, 'like' for taste, and 'like' for overall preference.
\end{abstract}

Keyword:characteristics, dry noodle, kepok banana

\section{PENDAHULUAN}

Pisang (Musa paradisiaca) merupakan jenis buah yang sudah dikenal luas di masyarakat, namun belum terlalu dikenal manfaat tanaman ini. Selain buah, batang dan daun, bonggol tanaman pisang dapat dimanfaatkan untuk keperluan pangan. Pemanfaatan bonggol tanaman pisang dapat dilakukan dengan mengolahnya menjadi tepung.

Pisang termasuk sebagai tanaman semusim yang setelah berbuah akan membentuk anakan dan mati. Di masyarakat terutama di daerah perkebunan pisang, setelah buah pisang dipanen maka pohon pisang akan segera ditebang hingga pada bonggol dan dibiarkan membusuk tanpa ada usaha untuk memanfaatkannya menjadi suatu produk yang berguna (Rismunandar, 2001).
Hampir semua bagian tanaman pisang kepok memiliki nilai guna dalam kehidupan sehari-hari. Bagian utama dari tanaman pisang kepok yang memiliki nilai sangat tinggi adalah buah pisang kepok. Bagian lain tanaman pisang kepok yang bisa dimanfaatkan adalah bonggol (corm). Bagian tanaman pisang kepok seperti bonggol, batang, kulit buah, dan jantung jarang dimanfaatkan dan dibuang begitu saja menjadi limbah pisang. Dua macam limbah tanaman pisang yaitu bonggol dan jantung ternyata mengandung gizi yang cukup tinggi dengan komposisi yang lengkap. Bonggol pisang mengandung karbohidrat (66\%), protein, air dan mineral-mineral penting (Munadjim,1983).

Saat ini pemanfaatan bonggol pisang kepok menjadi tepung masih jarang dilakukan, karena anggapan masyarakat yang menilai hasil olahan dari bahan baku 
tersebut memiliki mutu rendah. Beberapa hal yang mengakibatkan mutu tepung tersebut bermutu rendah diantaranya yaitu disebabkan oleh warna tepung yang coklat akibat pemanasan dan cita rasa yang kurang baik karena berasa agak sepat, oleh karena itu perlu pengkajian yang lebih dalam tentang pembuatan tepung bonggol pisang dan pengolahannya sebagai bahan baku mie. Untuk mengurangi ketergantungan terhadap tepung terigu dalam pembuatan mie seharusnya kita mencari bahan pengganti tepung terigu seperti tepung bonggol pisang.

Mie merupakan salah satu produk makanan yang disukai atau digemari oleh masyarakat hampir dari semua kalangan baik itu masyarakat perkotaan maupun pedesaan. Hal ini disebabkan bukan hanya karena rasanya yang cukup enak, tetapi juga cara penyajiannya yang praktis dan singkat. Makanan mie disajikan dalam berbagai bentuk masakan yang dijual mulai dari jajanan di pinggir jalan sampai ke restauran mewah (Anam dan Handajani, 2010).

Produk mie merupakan salah satu jenis olahan pangan yang sangat digemari oleh masyarakat Indonesia. Jenis produk mie yang mampu bersaing dipasar ialah mie kering. Mie kering diolah dengan tidak mengalami proses pemasakan lanjut ketika benang mie telah dipotong, melainkan mie segar yang langsung dikeringkan hingga kadar airnya mencapai 8-10\% (Mulyadi dkk, 2013).

\section{METODE}

\section{Bahan dan Alat}

Bahan yang digunakan dalam penelitian adalah bonggol pisang kapok (3 hari setelah panen) yang diperoleh dari petani pisang di Desa Laiba Kecamatan Labuan, tepung terigu, garam, air, telur, garam dan soda kue. Bahan yang digunakan dalam analisis adalah aquades, $\mathrm{NaOH}$ dan $\mathrm{HCl}$. Alat yang digunakan dalam penelitian adalah loyang, pisau, talenan, blender, ayakan, wadah/stoples, plastik bening (pembungkus) dan gilingan mie. Alat yang digunakan dalam analisis adalah label, oven, desikator, timbangan analitik, tabung reaksi, rak tabung reaksi, shaker, sentrifuge, wajan, pengaduk, kompor gas, cawan, saringan, gelas piala, stirrer, kertas saring, erlenmeyer dan corong Buchner.

\section{Metode}

Penelitian ini dilakukan dengan menggunakan Rancangan Acak Lengkap (RAL) dengan perlakuan konsentrasi tepung bonggol pisang (B) sebanyak 4 perlakuan yang diulang masing-masing 3 ulangan yaitu sebagai berikut :

B4 $=10 \%(20 \mathrm{~g})$ tepung bonggol pisang + $90 \%$ (180 g) tepung terigu

B3 $=20 \%$ (40 g) tepung bonggol pisang + $80 \%$ (160 g) tepung terigu

B2 $=30 \%(60 \mathrm{~g})$ tepung bonggol pisang + $70 \%$ (140 g) tepung terigu

$\mathrm{B} 1=40 \%(80 \mathrm{~g})$ tepung bonggol pisang + $60 \%(120 \mathrm{~g})$ tepung terigu

Data yang diperoleh dianalisis dengan sidik ragam, apabila dari sidik ragam menghasilkan pengaruh yang nyata pada taraf $\alpha 5 \%$ akan dilanjutkan dengan uji Beda Nyata Jujur (BNJ) pada taraf $\alpha$ $5 \%$. Peubah yang diamati dalam penelitian ini adalah uji daya serap air (Larrauri et al., 1996), cooking loss (CL) (Muhandri et al., 2012), kadar air (AOAC, 1990), kadar pati (AOAC, 1990), uji organoleptik (Soekarto, 1985). Adapun rancangan formula mie kering tepung bonggol pisang, seperti disajikan pada Tabel 1. 
Tabel 1Rancangan Formula Mie Kering Tepung Bonggol Pisang

\begin{tabular}{llllll}
\hline \multirow{2}{*}{ Komposisi } & \multirow{2}{*}{$\begin{array}{l}\text { Resep } \\
\text { Standar }\end{array}$} & \multicolumn{4}{l}{$\begin{array}{l}\text { Resep Mie Kering Tepung Bonggol Pisang } \\
\text { Tepung Bonggol Pisang : Tepung Terigu (\%) }\end{array}$} \\
\cline { 3 - 6 } & & $10: 90$ & $20: 80$ & $30: 70$ & $40: 60$ \\
\hline Tepung bonggol pisang & & $20 \mathrm{~g}$ & $40 \mathrm{~g}$ & $60 \mathrm{~g}$ & $80 \mathrm{~g}$ \\
Tepung terigu & $200 \mathrm{~g}$ & $180 \mathrm{~g}$ & $160 \mathrm{~g}$ & $140 \mathrm{~g}$ & $120 \mathrm{~g}$ \\
Telur & $1 \mathrm{btr}$ & $1 \mathrm{btr}$ & $1 \mathrm{btr}$ & $1 \mathrm{btr}$ & $1 \mathrm{btr}$ \\
Garam & $2 \mathrm{~g}$ & $2 \mathrm{~g}$ & $2 \mathrm{~g}$ & $2 \mathrm{~g}$ & $2 \mathrm{~g}$ \\
Soda kue & $0.5 \mathrm{~g}$ & $0.5 \mathrm{~g}$ & $0.5 \mathrm{~g}$ & $0.5 \mathrm{~g}$ & $0.5 \mathrm{~g}$ \\
Air & Secukupnya & Secukupnya & Secukupnya & Secukupnya & Secukupnya \\
\hline
\end{tabular}

HASIL DAN PEMBAHASAN

\section{Karakteristik Fisik Mie Kering}

\section{Daya Serap Air}

Data uji statistik menunjukkan substitusi tepung terigu dengan tepung bonggol pisang berpengaruh tidak nyata terhadap daya serap air mie, seperti disajikan pada Tabel 2 .

Tabel 2Daya Serap Air mie dari berbagai komposisi tepung bonggol pisang dengan tepung terigu

\begin{tabular}{ll}
\hline Komposisi T.Bonggol & Daya Serap \\
Pisang : T Terigu (\%) & Air Mie (\%) \\
\hline $10 \%: 90 \%$ & 4.59 \\
$20 \%: 80 \%$ & 4.40 \\
$30 \%: 70 \%$ & 4.58 \\
$40 \%: 60 \%$ & 4.47 \\
\hline
\end{tabular}

Tabel 2 menunjukkan bahwa mie dari bahan dasar berbagai komposisi tepung bonggol pisang dengan tepung terigu memiliki daya serap air (\%) antara $4.40 \%$ - $4.59 \%$, komposisi tepung bonggol pisang $10 \%$ dengan tepung terigu $90 \%$ memiliki daya serap air tertinggi (4.59\%) dan komposisi tepung bonggol pisang $20 \%$ dengan tepung terigu $80 \%$ memiliki daya serap air terendah $(4.40 \%)$.

Perubahan daya serap air mie disebabkan oleh adanya perbedaan komponen penyusun bahan, kandungan amilosa dan tingkat pemanasan yang dilakukan pada saat proses pengolahan (Hadiningsih, 1999). Substitusi tepung terigu dengan tepung bonggol pisang tidak berpengaruh nyata terhadap daya serap air mie yang dihasilkan, diduga karena tepung bonggol pisang memiliki komposisi kimia (kadar air $10.555 \%$ ) yang memenuhi SNI 01-3751-2006 tepung (maksimal 14.5\%).

\section{Cooking Loss}

Data uji statistik menunjukkan bahwa komposisi tepung bonggol pisang dengan tepung terigu berpengaruh nyata terhadap cooking loss mie, seperti disajikan pada Tabel 3.

Tabel 3Cooking loss mie dari berbagai komposisi tepung bonggol pisang dengan tepung terigu

\begin{tabular}{ll}
\hline $\begin{array}{l}\text { Komposisi T.Bonggol } \\
\text { Pisang : T Terigu (\%) }\end{array}$ & $\begin{array}{l}\text { Cooking loss } \\
(\%) \text { mie }\end{array}$ \\
\hline $10 \%: 90 \%$ & $0.57 \mathrm{a}$ \\
$20 \%: 80 \%$ & $0.60 \mathrm{ab}$ \\
$30 \%: 70 \%$ & $0.62 \mathrm{~b}$ \\
$40 \%: 60 \%$ & $0.73 \mathrm{c}$ \\
\hline BNT $\alpha=0.05$ & 0.03 \\
\hline
\end{tabular}

Keterangan : Angka-angka yang diikuti dengan huruf sama pada kolom yang sama menunjukkan berbeda tidak nyata pada taraf uji BNT $\alpha=0.05$

Tabel 3 menunjukkan bahwa mie yang berbahan dasar $10 \%$ tepung bonggol pisang dengan $90 \%$ tepung terigu memiliki cooking loss terendah $(0.57 \%)$ berbeda nyata dengan perlakuan $30 \%$ tepung bonggol pisang : $70 \%$ tepung terigu dan perlakuan $40 \%$ tepung bonggol pisang : $60 \%$ tepung terigu namun berbeda tidak nyata dengan perlakuan 
$20 \%$ tepung bonggol pisang : $80 \%$ tepung terigu. Cooking loss atau kehilangan padatan mie akibat pemasakan merupakan banyaknya padatan yang terkandung dalam mie yang keluar dan terlarut ke dalam air selama pemasakan (Hadiningsih, 1999). Hasil penelitian menunjukkan bahwa semakin tinggi persentase tepung bonggol pisang sebagai bahan baku mie, maka semakin tinggi pula cooking loss mie pada saat pemasakan. Sedangkan semakin tinggi persentase tepung terigu sebagai bahan baku mie, maka semakin rendah cooking loss mie pada saat pemasakan. Hal ini sesuai dengan pendapat Safriani, dkk (2013) yang menyatakan bahwa tepung terigu mengandung gluten pati yang dapat mencegah pelepasan komponen pati.

\section{Karakteristik Kimia Mie Kering Kadar Air}

Kadar air berpengaruh terhadap masa simpan dan tekstur produk. Mie kering mempunyai masa simpan yang relatif panjang karena mempunyai kadar air yang rendah yaitu sekitar 8-10\%. Menurut Astawan (2006), mie kering adalah mie mentah yang telah dikeringkan hingga kadar airnya mencapai $8-10 \%$. Data uji statistik menunjukkan bahwa komposisi tepung bonggol pisang dengan tepung terigu berpengaruh nyata terhadap kadar air mie, seperti disajikan pada Tabel 4.

Tabel 4Kadar air (\%) mie dari berbagai komposisi tepung bonggol pisang dengan tepung terigu

\begin{tabular}{lll}
\hline $\begin{array}{l}\text { Komposisi T. Bonggol } \\
\text { Pisang : T Terigu }(\%)\end{array}$ & $\begin{array}{l}\text { Kadar air } \\
(\%) \text { mie }\end{array}$ & $\begin{array}{l}\text { BNT } \alpha \\
=0.05\end{array}$ \\
\hline $10 \%: 90 \%$ & $10.37 \mathrm{a}$ & \\
$20 \%: 80 \%$ & $11.58 \mathrm{~b}$ & \\
$30 \%: 70 \%$ & $12.00 \mathrm{bc}$ & 0.84 \\
$40 \%: 60 \%$ & $15.71 \mathrm{c}$ & \\
\hline
\end{tabular}

Keterangan : Angka-angka yang diikuti dengan huruf sama pada kolom yang sama menunjukkan berbeda tidak nyata pada taraf uji BNT $\alpha=0.05$

Tabel 4 menunjukkan bahwa mie yang berbahan dasar 10\% tepung bonggol pisang dengan $90 \%$ tepung terigu memiliki kadar air terendah $(10.37 \%)$ berbeda nyata dengan semua perlakuan. Hal ini menunjukkan bahwa semakin rendah persentase substitusi tepung bonggol pisang akan diikuti dengan penurunan kadar air mie.

Kadar air mie sangat dipengaruhi oleh kadar air tepung yang digunakan sebagai bahan baku, hal ini karena dengan adanya serat pada tepung bonggol pisang sebagai bahan baku pembuatan mie. Sesuai dengan pendapat Wesiaji (2011) bahwa substitusi tepung terigu terhadap tepung bonggol pisang berpengaruh terhadap kadar air karena dengan adanya serat pada cookies yang disebabkan adanya substitusi bonggol pisang menyebabkan penyerapan air yang berbeda dari setiap perlakuan, semakin tinggi kandungan serat maka kandungan air pada cookies semakin bertambah pula. Serat memiliki kemampuan untuk menyerap air sehingga menambah kandungan air pada cookies. Sesuai juga dengan pendapat Muchtadi dan Palupi (1992) bahwa salah satu fungsi serat adalah dapat mengikat air yang akhirnya menyebabkan kandungan air dalam suatu bahan makanan bertambah.

Menurut data BSN yaitu SNI 013751-2006 disebutkan bahwa kadar air pada tepung terigu maksimal sebesar 14.5\%. Dapat diketahui bahwa kadar air pada tepung bonggol pisang masih memenuhi Standar Nasional Indonesia, tepung bonggol pisang memiliki kadar air $10.61 \%$ yang diperoleh pada penelitian.

\section{Kadar Pati}

Data uji statistik menunjukkan bahwa komposisi tepung bonggol pisang dengan tepung terigu berpengaruh tidak nyata terhadap kadar pati mie, seperti disajikan pada Tabel 5. 
Tabel 5Kadar Pati mie dari berbagai komposisi tepung bonggol pisang dengan tepung terigu.

\begin{tabular}{ll}
\hline Komposisi T.Bonggol & Kadar Pati \\
Pisang : T Terigu (\%) & Mie (\%) \\
\hline $10 \%: 90 \%$ & 34.21 \\
$20 \%: 80 \%$ & 35.27 \\
$30 \%: 70 \%$ & 31.77 \\
$40 \%: 60 \%$ & 29.51 \\
\hline
\end{tabular}

Tabel 5 menunjukkan bahwa mie berbahan dasar berbagai komposisi tepung bonggol pisang dengan tepung terigu memiliki kadar pati antara $29.51 \%$ $35.27 \%$, namun kadar pati tertinggi (35.27\%) diperoleh dari komposisi $20 \%$ tepung bonggol pisang dengan $80 \%$ tepung terigu dan kadar pati terendah (29.51\%) diperoleh dari komposisi $40 \%$ tepung bonggol pisang dengan $60 \%$ tepung terigu.

Kadar pati substitusi tepung bonggol pisang yang berbeda tidak nyata pada setiap perbandingan persentase tepung bonggol pisang dengan tepung terigu, menunjukkan bahwa tepung bonggol pisang memiliki kandungan pati yang hampir sama dengan tepung terigu. Hasil ini juga didukung oleh parameter daya serap air mie yang berbeda tidak nyata pada semua perbandingan persentase tepung bonggol pisang dan tepung terigu.

Komponen terbesar tepung terigu adalah pati. Pati terdiri dari dua fraksi yang dapat dipisahkan dengan air panas. Fraksi terlarut disebut amilosa dan fraksi tidak terlarut disebut dengan amilopektin (Winarno, 1997 dalam Azizah, 2009).

\section{Karakteristik Organoleptik Mie Warna}

Data uji statistik menunjukkan bahwa perbandingan persentase substitusi tepung bonggol pisang berpengaruh nyata terhadap penerimaan warna mie oleh panelis, seperti disajikan pada Tabel 6.
Tabel 6Skor penilaian panelis terhadap warna mie dari berbagai komposisi tepung bonggol pisang dengan tepung terigu

\begin{tabular}{|c|c|c|}
\hline $\begin{array}{l}\text { Komposisi } \\
\text { T.Bonggol Pisang : } \\
\text { T Terigu }(\%)\end{array}$ & $\begin{array}{l}\text { Skor penilaian } \\
\text { warna mie oleh } \\
\text { panelis }\end{array}$ & $\begin{array}{l}\text { BNT } \\
\alpha \quad= \\
0.05\end{array}$ \\
\hline $10 \%: 90 \%$ & $4.84 \mathrm{a}$ & \multirow{4}{*}{0.13} \\
\hline $20 \%: 80 \%$ & $4.28 \mathrm{~b}$ & \\
\hline $30 \%: 70 \%$ & $2.96 \mathrm{c}$ & \\
\hline $40 \%: 60 \%$ & $2.84 \mathrm{c}$ & \\
\hline
\end{tabular}

Keterangan : Angka-angka yang diikuti dengan huruf sama pada kolom yang sama menunjukkan berbeda tidak nyata pada taraf uji BNT $\alpha=0.05$

Tabel 6 menunjukkan bahwa mie yang berbahan dasar $10 \%$ tepung bonggol pisang dan $90 \%$ tepung terigu, diberikan penilaian warna oleh panelis dengan skor 4.85 (skala hedonik "sangat suka"), berbeda nyata dengan perlakuan perbandingan persentase tepung bonggol pisang dengan tepung terigu lainnya. Namun dengan mengacu pada uji sensoris, maka mie yang berbahan dasar $20 \%$ tepung bonggol pisang dan $80 \%$ tepung terigu, diberikan penilaian warna oleh panelis dengan skor 4.28 (skala hedonik "suka").

Warna mie substitusi tepung bonggol pisang $10 \%$ dan $20 \%$, dinilai oleh panelis dengan skala hedonik sangat suka dan suka. Hal ini menunjukkan bahwa tepung terigu sebagai bahan dasar mie dapat disubstitusi oleh tepung bonggol pisang hingga 20\%. Hal ini Sesuai dengan pendapat Saragih, dkk (2007) bahwa masalah utama substitusi tepung bonggol pisang adalah warna mie yang dihasilkan agak kecoklatan jika penambahan tepung bonggol pisang lebih di atas $10 \%$.

\section{Aroma}

Aroma merupakan faktor penting dalam menentukan tingkat penerimaan konsumen pada suatu bahan, aroma banyak menentukan kelezatan bahan makanan, biasanya seseorang dapat menilai lezat tidaknya suatu bahan 
makanan dari aroma yang ditimbulkan (Soekarto, 1985).

Data uji statistik menunjukkan bahwa perbandingan persentase substitusi tepung bonggol pisang berpengaruh nyata terhadap penerimaan aroma mie oleh panelis, seperti disajikan pada Tabel 7.

Tabel 7Skor penilaian panelis terhadap aroma mie dari berbagai komposisi tepung bonggol pisang dengan tepung terigu

\begin{tabular}{|c|c|c|}
\hline $\begin{array}{l}\text { Komposisi } \\
\text { T.Bonggol Pisang } \\
\text { : T Terigu }(\%) \\
\end{array}$ & $\begin{array}{l}\text { Skor penilaian } \\
\text { aroma mie oleh } \\
\text { panelis }\end{array}$ & $\begin{array}{l}\text { BNT } \\
\alpha= \\
0.05\end{array}$ \\
\hline $10 \%: 90 \%$ & $4.44 \mathrm{a}$ & \multirow{4}{*}{0.11} \\
\hline $20 \%: 80 \%$ & $4.52 \mathrm{a}$ & \\
\hline $30 \%: 70 \%$ & $3.72 \mathrm{~b}$ & \\
\hline $40 \%: 60 \%$ & $3.80 \mathrm{~b}$ & \\
\hline
\end{tabular}

Keterangan : Angka-angka yang diikuti dengan huruf sama pada kolom yang sama menunjukkan berbeda tidak nyata pada taraf uji BNT $\alpha=0.05$

Tabel 7 menunjukkan bahwa mie yang berbahan dasar $20 \%$ tepung bonggol pisang dan $80 \%$ tepung terigu, diberikan penilaian aroma tertinggi oleh panelis dengan skor 4.52 (skala hedonik "sangat suka") berbeda tidak nyata dengan mie yang berbahan dasar 10\% tepung bonggol pisang dan $90 \%$ tepung terigu, namun berbeda nyata dengan perlakuan perbandingan persentase tepung bonggol pisang dengan tepung terigu lainnya. Penerimaan panelis terhadap warna, aroma, rasa dan tekstur mie yang dihasilkan menurun dengan meningkatnya substitusi tepung bonggol pisang (Saragih, dkk., 2007).

\section{Tekstur}

Tekstur merupakan sensasi tekanan yang dapat diamati dengan mulut (pada waktu digigit, dikunyah, dan ditelan) ataupun perabaan dengan jari (Kartika dkk., 1988). Data uji statistik menunjukkan bahwa perbandingan persentase substitusi tepung bonggol pisang berpengaruh nyata terhadap penerimaan tekstur mie oleh panelis, seperti disajikan pada Tabel 8.

Tabel 8Skor penilaian panelis terhadap tekstur mie dari berbagai komposisi tepung bonggol pisang dengan tepung terigu

\begin{tabular}{lll}
\hline $\begin{array}{l}\text { Komposisi } \\
\text { Bonggol Pisang }\end{array}$ & $\begin{array}{l}\text { Skor penilaian } \\
\text { tekstur }\end{array}$ mie & $\begin{array}{l}\text { BNT } \\
\text { T Terigu }(\%)\end{array}$ \\
oleh panelis & 0.05 \\
\hline $10 \%: 90 \%$ & $4.56 \mathrm{a}$ \\
$20 \%: 80 \%$ & $4.44 \mathrm{~b}$ & \\
$30 \%: 70 \%$ & $3.68 \mathrm{c}$ & 0.10 \\
$40 \%: 60 \%$ & $3.48 \mathrm{c}$ \\
\hline
\end{tabular}

Tabel 8 menunjukkan bahwa mie yang berbahan dasar 10\% tepung bonggol pisang dan $90 \%$ tepung terigu, diberikan penilaian tekstur terbaik oleh panelis dengan skor 4.56 (skala hedonik "sangat suka") berbeda nyata dengan semua perlakuan perbandingan persentase tepung bonggol pisang dengan tepung terigu lainnya. Namun, dengan mengacu pada uji sensoris maka mie yang berbahan dasar $20 \%$ tepung bonggol pisang dan $80 \%$ tepung terigu, juga disukai oleh panelis sehingga diberikan penilaian tekstur dengan skor 4.44 (skala hedonik " suka"). Hal ini menunjukkan bahwa tepung terigu sebagai bahan dasar mie dapat disubstitusi oleh tepung bonggol pisang hingga $20 \%$. Sesuai dengan Saragih, dkk (2007) bahwa penerimaan panelis terhadap warna, aroma, rasa dan tekstur mie yang dihasilkan menurun dengan meningkatnya substitusi tepung bonggol pisang.

\section{Rasa}

Rasa merupakan sensasi yang diproduksi oleh material yang dimasukkan ke dalam mulut, dirasakan prinsipnya oleh indera perasa dalam mulut. Data uji statistik menunjukkan bahwa perbandingan persentase substitusi tepung bonggol pisang berpengaruh nyata 
terhadap penerimaan rasa mie oleh panelis, seperti disajikan pada Tabel 9.

Tabel 9Skor penilaian panelis terhadap rasa mie dari berbagai komposisi tepung bonggol pisang dengan tepung terigu

\begin{tabular}{|c|c|c|}
\hline $\begin{array}{l}\text { Komposisi } \\
\text { T.Bonggol Pisang } \\
\text { T Terigu (\%) }\end{array}$ & $\begin{array}{l}\text { Skor penilaian } \\
\text { rasa mie oleh } \\
\text { panelis }\end{array}$ & $\begin{array}{l}\text { BNT } \\
\alpha= \\
0.05\end{array}$ \\
\hline $10 \%: 90 \%$ & $4.16 \mathrm{a}$ & \multirow{4}{*}{0.13} \\
\hline $20 \%: 80 \%$ & $3.76 \mathrm{~b}$ & \\
\hline $30 \%: 70 \%$ & $2.96 \mathrm{c}$ & \\
\hline $40 \%: 60 \%$ & $2.68 \mathrm{~d}$ & \\
\hline
\end{tabular}

Keterangan : Angka-angka yang diikuti dengan huruf sama pada kolom yang sama menunjukkan berbeda tidak nyata pada taraf uji BNT $\alpha=0.05$

Tabel 9 menunjukkan bahwa mie yang berbahan dasar 10\% tepung bonggol pisang dan $90 \%$ tepung terigu, diberikan penilaian rasa tertinggi oleh panelis dengan skor 4.16 (skala hedonik "suka") berbeda nyata dengan semua perlakuan lainnya. Hal ini menunjukkan bahwa semakin rendah persentase substitusi tepung bonggol pisang, maka semakin meningkat penerimaan rasa mie oleh panelis. Sehingga besarnya substitusi tepung bonggol pisang sebagai bahan dasar pembuatan mie adalah $10 \%$. Sesuai dengan pendapat Saragih, dkk (2007) bahwa substitusi tepung bonggol pisang terhadap rasa, warna, aroma dan tekstur mie yang dihasilkan maksimum $10 \%$.

\section{Tingkat Kesukaan}

Uji tingkat kesukaan (overall) dilakukan setelah panelis mengenal warna, aroma, tekstur dan rasa suatu produk pangan. Data uji statistik menunjukkan bahwa perbandingan konsentrasi tepung bonggol pisang berpengaruh nyata terhadap kesukaan panelis terhadap produk mie dari berbagai substitusi tepung terigu dengan tepung bonggol pisang, seperti disajikan pada Tabel 10.
Tabel 10Skor penilaian kesukaan panelis terhadap produk mie dari berbagai komposisi tepung bonggol pisang dengan tepung terigu

\begin{tabular}{|c|c|c|}
\hline $\begin{array}{l}\text { Komposisi } \\
\text { T.Bonggol Pisang } \\
\text { : T Terigu }(\%)\end{array}$ & $\begin{array}{l}\text { Skor penilaian } \\
\text { panelis terhadap } \\
\text { produk mie }\end{array}$ & $\begin{array}{l}\text { BNT } \\
\alpha= \\
0.05\end{array}$ \\
\hline $10 \%: 90 \%$ & $4.88 \mathrm{a}$ & \multirow{4}{*}{0.11} \\
\hline $20 \%: 80 \%$ & $4.36 \mathrm{a}$ & \\
\hline $30 \%: 70 \%$ & $3.56 \mathrm{~b}$ & \\
\hline $40 \%: 60 \%$ & $3.40 \mathrm{~b}$ & \\
\hline
\end{tabular}

Keterangan : Angka-angka yang diikuti dengan huruf sama pada kolom yang sama menunjukkan berbeda tidak nyata pada taraf uji BNT $\alpha=0.05$

Tabel 10 menunjukkan bahwa produk mie yang berbahan dasar 10\% tepung bonggol pisang dan $90 \%$ tepung terigu lebih disukai oleh panelis dengan skor penerimaan 4.88 (skala hedonik "sangat suka") berbeda nyata dengan perlakuan perbandingan persentase tepung bonggol pisang dengan tepung terigu lainnya. Namun dengan mengacu pada uji sensoris maka produk mie yang berbahan dasar $20 \%$ tepung bonggol pisang dan $80 \%$ tepung terigu juga disukai oleh panelis dengan skor penerimaan 4.36 (skala hedonik "suka") Hal ini menunjukkan bahwa semakin rendah persentase substitusi tepung bonggol pisang, maka semakin meningkat penerimaan rasa mie oleh panelis. Sehingga besarnya substitusi tepung bonggol pisang sebagai bahan dasar pembuatan mie adalah 10\%-20\%. Menurut Winarno dan Rahayu (1994) dalam Saragih, dkk (2007) bahwa Rasa, aroma, warna serta penampilan makanan akan mempengaruhi tingkat kesukaan masyarakat terhadap makanan.

\section{KESIMPULAN}

Adapun kesimpulan yang dapat ditarik dari penelitian ini adalah sebagai berikut :

1. Komposisi perbandingan persentase tepung bonggol pisang dengan tepung terigu berpengaruh nyata terhadap karakteristik fisik, kimia dan organoleptik mie kering. 
2. Mie kering dengan bahan dasar tepung bonggol pisang $10 \%$ dengan tepung terigu $90 \%$ memiliki karakteristik fisik dan kimia terbaik. Karakteristik fisik yaitu daya serap air (4.59\%) dan cooking loss $(0.57 \%)$, karakteristik Kimia yaitu kadar air (10.37\%) dan kadar pati (34.21\%) sedangkan karakteristik sensoris mie kering hingga konsentrasi 20\% tepung bonggol pisang dengan $80 \%$ tepung terigu disukai oleh panelis.

\section{DAFTAR PUSTAKA}

Anam, C. dan S. Handajani. 2010. Mi Kering Waluh (Cucurbita moschata) dengan Antioksidan dan Pewarna Alami. Jurnal Caraka Tani XXV No. 1

AOAC, Assn. of Official Analytical Chemists. 1990. Official methods of analysis. Method 985.29. 15th (eds). Washington D.C.

Astawan, M., 2006. Membuat Mie dan Bihun. Penebar Swadaya, Jakarta.

Azizah T N. 2009. Kajian Pengaruh Substitusi Parsial Tepung Terigu dengan Tepung Daging Sapi dalam Pembuatan Kreker terhadap Kerenyahan dan Sifat Sensori Kreker Selama Penyimpanan. Skripsi. Departemen Tekhnologi Hasil Ternak, Fakultas Peternakan, IPB, Bogor.

Badan Standarisasi Nasional. 1996. Standar Nasional Mi Kering No. 012974-1996. BSN. Jakarta.

Badan Standarisasi Nasional. 2006. Standar Nasional Indonesia. SNI 013751-2006. Tepung Terigu sebagai Bahan Makanan. Badan Standardisasi Nasional. Jakarta.

Departemen Perindustrian. 1992. Standar Mutu Mie Kering (SNI No. 012794-1992).

Departemen

Perindustrian RI, Jakarta.

Hadiningsih N., 1999. Pemanfaatan tepung jagung sebagai bahan pensubstitusi terigu dalam pembuatan produk mie kering yang difortifikasi dengan tepung bayam. Skripsi Fakultas Teknolgi Pertanian IPB, Bogor

Larrauri et al, 1996. High dietary fibre powders from orange and lime peels: Associated polyphenols and antioxidant capacity. Food Res. Int.,

Muchtadi D dan Palupi NS. 1992. Metoda Kimia Biokimia dan Biologi dalam Evaluasi Nilai Gizi Pangan Olahan. Departemen pendidikan dan dan Kebudayaan Direktorat Jenderal Pendidikan Tinggi Pusat antar Universitas Pangan dan Gizi. Institut Pertanian Bogor, Bogor.

Muhandri, T., Zulkhaiar, H., Subarna, Nurtama, B. 2012. Komposisi Kimia Tepung Jagung Varietas Unggul Lokal dan Potensinya untuk Pembuatan Mi Jagung Menggunakan Ekstruder Pencetak. 02 Jurnal Sains Terapan Edisi II Vol-2 (1) : 16 - 31 (2012)

Mulyadi, A. F., Wignyanto, Budiarti, A. N. 2013. Pembuatan Mie Kering Kemangi (Ocimum sanctum L.) dengan Bahan Dasar Tepung Terigu dan Tepung Mocaf (Modified Cassava Flour) (Kajian Jenis Perlakuan dan Konsentrasi Kemangi). Jurnal Teknologi Industri Pertanian

Mulyati, S. 2005. Tekhno Pangan, Aneka Olahan Pisang. Trubus Agrisarana, Jakarta

Munadjim.1983. Teknologi Pengolahan Pisang. PT Gramedia. Jakarta

Rismunandar. 2001. Bertanam Pisang. Sinar Baru Algensindo. Bandung.

Safriani, N., Moulana, R., Ferizal. 2013. Pemanfaatan Pasta Sukun (Artocarpus altilis) pada Pembuatan Mi Kering. Jurnal Teknologi dan Industri Pertanian Indonesia Vol. (5) No. 2 
Saragih, B., F. K. Odit, dan S. Andi. 2007. Kajian pemanfaatan Tepung Bonggol Pisang (Musa paradisiaca Linn) sebagai Substitusi Tepung Terigu dalam Pembuatan Mie basah. Jurnal Teknologi Pertanian. 3 (2) : 63-6

Soekarto, 1985. Penelitian Organoleptik untuk Industri Pangan dan Hasil
Pertanian. Bharata Karya Aksara, Jakarta.

Wesiaji. S. N. 2011. Subtitusi Tepung Terigu terhadap Tepung Bonggol Pisang (Musa paradisiaca linn) pada Pembuatan Cookies. Skripsi Teknologi Hasil Pertanian. Universitas Mulawarman, 